\title{
The diet and feeding behaviour of the black-and-white colobus (Colobus guereza) in the Kalinzu Forest, Uganda
}

Ikki Matsuda $^{1 *}$, Hiroshi Ihobe ${ }^{2}$, Yasuko Tashiro ${ }^{3}$, Takakazu Yumoto $^{3}$, Deborah Baranga ${ }^{4}$, Chie Hashimoto ${ }^{3}$

1. Chubu University Academy of Emerging Sciences, 1200, Matsumoto-cho, Kasugai-shi, Aichi 487-8501, Japan; Wildlife Research Center of Kyoto University, Kyoto, Japan; Japan Monkey Centre, 26 Kanrin, Inuyama, Aichi, Japan; Institute for Tropical Biology \& Conservation, Universiti Malaysia Sabah, Kota Kinabalu, Sabah, Malaysia;

Email: ikki-matsuda@isc.chubu.ac.jp

Tel: $+81-568-51-9907$

Fax: +81-568-51-6496 (ext.8829)

2. School of Human Sciences, Sugiyama Jogakuen University, Nagoya, Aichi, Japan

3. Primate Research Institute, Kyoto University, Inuyama, Aichi, Japan

4. Department of Zoology, Entomology and Fisheries Sciences, College of Natural Sciences, Makerere University

* Author for correspondence 


\section{Abstract}

One of the goals for primate feeding ecology is to understand the factors that affect inter- and intra-specific variations. Therefore, a detailed description of basic feeding ecology in as many populations and sites as possible is necessary and warrants further understanding. The black-and-white colobus (Colobus guereza) or guereza is widely distributed in Africa and is one of the well-studied colobines in terms of their feeding; they demonstrate considerable variation in their diets in response to local conditions. We studied the diet of a group of guerezas in the Kalinzu Forest, Uganda, for over 30 consecutive months using behavioural observation (4,308 h total), phenology, and vegetation surveys. A total of 31 plant species were consumed by the study group. This study group was predominantly folivorous; the majority of their feeding time was involved in feeding on young leaves (87\%). However, during certain times of the year, fruits and seeds accounted for $45 \%$ of monthly feeding time. Young leaves of Celtis durandii were by far the most important food, which constituted $58 \%$ of the total feeding records. There was a significant increase in the consumption of fruits and flowers once young leaf availability was low, but their consumption of fruits did not significantly increase even when fruit availability was high. Their monthly dietary diversity increased as the number of available plants with young leaves declined, suggesting that much of the dietary diversity in the study group may be attributable to the young leaf portion of their diet. Our findings may help contribute to a better understanding of the dietary adaptations and feeding ecology of guerezas in response to local environmental conditions.

\section{Keywords}

Celtis durandii; colobines; folivory; foregut-fermenter; foraging; guereza 


\section{Introduction}

A considerable amount of knowledge has been accumulated over the past few decades with respect to the dietary information of non-human primates. This has not only served to increase researchers' knowledge regarding the diet of primates but also contributed in understanding their dietary flexibility in response to the environment (Campbell et al. 2011). Such flexible variations in diet serve to satisfy their nutritional requirements in habitats with seasonally fluctuating food availability, which is influenced by various environmental factors, such as temperature, rainfall, and plant phenology (Hanya et al. 2013; Hemingway and Bynum 2005). Thus, an assessment of dietary variation in relation to seasonal conditions is important for evaluating primate foraging strategies.

Colobine monkeys, which include at least 30 species grouped into 4-9 genera in Asia and Africa (Oates et al. 1994), feed on difficult-to-process foods, including leaves, seeds, and unripe fruits, which they process in their complex, multi-chambered stomachs, wherein bacteria detoxify chemicals from defensive plants and digest cellulose (Chivers 1994). Previously it was assumed that colobine monkeys primarily exploit ubiquitous food sources like leaves because of their foregut-fermentation digestive system; however, there is evidence of considerable variation in their diet (in some cases, they rely heavily on fruits) (Fashing 2011; Kirkpatrick 2011). Particularly, colobines in clades with tripartite stomachs (without praesaccus) tend to rely more on fruits and seeds for food during times when fruits are readily availability (Matsuda et al. 2019).

Foregut-fermenting black-and-white colobuses, aka guerezas (Colobus guereza), with tripartite stomachs, which is the species of the genus most widely distributed in Africa (Zinner et al. 2019), have been reported to have considerably varied diets. Some populations have been documented as highly folivorous (Clutton-Brock 1975; Harris and Chapman 2007; Hussein et al. 2017; Oates 1977; Wasserman and Chapman 2003), whereas others eat large quantities of fruit (Fashing 2001; Poulsen et al. 2002). Because one of the goals of feeding ecology is to understand the factors that affect such intra-specific dietary variations across different populations and sites, a detailed description of as many populations and sites as possible is 
imperative to further this understanding.

We studied the diet of guerezas in the Kalinzu Forest, Uganda, for over 30 consecutive months. We aim to describe the dietary changes among its different species in response to seasonal fluctuations and availability of certain food, including leaves, flowers and fruits. This study presents the systematic information regarding the feeding habits and monthly dietary variation of guerezas in this study site.

\section{Methods}

\section{Study site and focal group}

Observations were conducted from November 2013 to April 2016 in a moist, medium-altitude evergreen forest in the Kalinzu Forest in western Uganda, covering an area of $137 \mathrm{~km}^{2}\left(30^{\circ} 07^{\prime} \mathrm{E}, 0^{\circ} 17^{\prime} \mathrm{S}\right.$; altitude 1,000-1,500 $\mathrm{m}$ above sea level) (Hashimoto et al. 1999). From November 2013 to April 2016, the mean minimum and maximum daily temperatures were approximately $14.0^{\circ} \mathrm{C}(\mathrm{SD}: 1.9)$ and $27.2^{\circ} \mathrm{C}$ (SD: 2.1), respectively. The annual precipitation at the site in 2015 was $1370 \mathrm{~mm}$.

From November 2011 to October 2012, preliminary observations were performed on several guereza groups before the most habituated group was chosen for the study. During these preliminary observations, members of a focal group were identified by describing their individual physical characteristics. At the end of the preliminary observations, the study group included 11 individuals: one alpha male, three adult females, two subadult females, two juveniles, and three infants.

\section{Behavioural data collection}

We observed the habituated focal group for $10-22 \mathrm{~d} /$ mo from approximately 7:30 to 16:00. During the observation periods, we conducted scan sampling at 10-min intervals. We recorded the activity (feeding, moving, and resting) of all visible adults and subadults ranging from 1-7 individuals with a mean number of $4.8 \pm$ SD 1.2 individuals per scan. We recorded the food category and collected samples for later identification when they were feeding. We collected data for 30 months from November 2013 to April 2016, except when data collection was interrupted by a field accident in November 2014. 
The total observation time was 4,308 h, and the monthly observation time was 69-185 $\mathrm{h}$ (mean: $139 \pm \mathrm{SD} 34 \mathrm{~h}$ ). The observation time per day was $8.00 \pm \mathrm{SD} 1.01 \mathrm{~h}$.

\section{Vegetational and phenological survey}

In addition to the ten parallel transects, each of which was $5 \mathrm{~km}$ in length and built no earlier than 1997 (Hashimoto et al. 1999), to assist in observation and focal following, a trails system was set up in the study site. Based on the ranging data of the focal group during the preliminary observation time, we selected 12 trails that were 180-900 m long (total 4,700 m). We labeled trees $\geq 10 \mathrm{~cm}$ in diameter at breast height $(\mathrm{DBH})$ and vines $\geq 5 \mathrm{~cm}$ in diameter located $\leq 1.5 \mathrm{~m}$ from the trail; hence, the labeled width was $3 \mathrm{~m}$, and the vegetation survey area covered 1.41 ha $(3 \mathrm{~m} \times 4,700 \mathrm{~m})$. All labeled trees and vines were taxonomically identified from the Makerere University Herbarium. At the end of the monthly survey, the phenology of the 996 labeled plants along the 12 trails was recorded by examining each plant for the presence or absence of fruits (both ripe and unripe) and flowers (including floral buds). We also recorded the presence or absence of young leaves but used their abundance score, i.e., 1 : < $20 \%$ of young leaves in a tree, 2 : $20 \%<50 \%$, and $3: 50 \% \leq 100 \%$.

\section{Data analysis}

Data were tested for normality using the Kolmogorov-Smirnov test. To test the correlations between the monthly availability of each plant part (young leaves, fruits, and flowers) and feeding activity on each plant part, data were measured using either the parametric Pearson correlation coefficient for variables that were normally distributed or the nonparametric Spearman's rank correlation coefficient for variables that were not normally distributed. We used the Holm sequential Bonferroni procedure to correct for multiple comparisons (Holm 1979) and applied the corrected $P$-values. The Shannon-Wiener index of diversity $\left(H^{\prime}\right)$ (Pielou 1966) was used to calculate the dietary diversity of each month. The linear mixed model was used to examine whether the monthly dietary diversity of guerezas (response variable) was affected by the availability of leaves, fruits, and/or flowers (explanatory variables). The variance 
inflation factors were smaller than the cut-off value, i.e., 10 (Quinn and Keough 2002). The Akaike information criterion for small samples (AICc value: Burnham and Anderson 2002) was used to find a good-fitting model ( $\triangle \mathrm{AICc}<2$, i.e., the AICc in a model is less than two units larger than in the best model). We used R 3.53 for all the statistical analyses (R-Core-Development-Team 2019), and the significance level was set at 0.05 .

\section{Results}

\section{Vegetation and phenology}

We marked 969 trees and 27 vines (68 species, 57 genera, 35 families) along our 12 trails (Table 1). The five most abundant families were Apocynaceae (20.7\% of all plants), Meliaceae (12.7\%), Oleaceae (10.1\%), Rubiaceae (9.4\%), and Cannabaceae (9.0\%). The five most abundant plant species were Funtumia africana (18.5\% of all trees), Carapa procera (12.0\%), Strombosia scheffleri (10.1\%), Celtis durandii (8.0\%), and Musanga leo-errerae (5.4\%). The vegetation survey area covered 1.41 ha (3 m $\times 4,700 \mathrm{~m}$ ). The cumulative number of plant species did not appear to reach an asymptote (Fig.1), probably because of the high species diversity in the tropical secondary forest. However, the total number of plant species used as a food source by the study group (39 plant species) was lower than that described in the vegetation survey, indicating that the results of vegetation survey represent the composition of the available plant species by the study group.

Of the 969 trees and vines along the trails, 515 (53.3\%) were plant species that we observed the study group to use as a food sources. This included 505 plants with young leaves (52.2\%), 392 with fruits (41.0\%), and 148 with flowers (15.3\%). Food availability, determined as the number of young leafing (but applied scored numbers: see in Methods), fruiting, and flowering potential food plants in the monthly phenological survey, fluctuated seasonally with several peaks within a year (Fig. 2). Young leaves were generally available during all seasons and were more abundant than fruits and flowers. 


\section{Overall food habits}

The study group frequently consumed young leaves, fruits and flowers; they occasionally consumed mature leaves and other food types including the tree bark of Carapa procera and Eucalyptus grandis and soil on the ground. The total number of plant species consumed by the group of guerezas during 4,308 h of observation was 31 , including two unidentified species (26 genera, 24 families; Table 2); it was 39 plant species including the preliminary observation time. A number of plant species that provided leaves, fruits/seeds, and flowers were 31, 12, and 6, respectively. Overall, the study group fed on young leaves (87.0\% of feeding record); fruits $(9.8 \%)$, including seeds $(5.0 \%)$, both seeds and pulp of ripe (4.5\%) and unripe fruits $(0.3 \%)$; flowers $(1.1 \%)$; bark $(0.9 \%)$; soil $(0.8 \%)$; and other foods (unspecified foods and mature leaf: $0.4 \%$ ). Young leaves of Celtis durandii (Cannabaceae) were by far the most important food, which constituted $58.1 \%$ of the total feeding records, followed by the young leaves of Prunus africana (Rosaceae: 11.0\%) and the fruits including seeds of $C$. durandii $(4.8 \%)$.

\section{Monthly variation in diet and dietary diversity}

We analyzed the seasonal changes in diet to examine the effects of temporal changes in the availability of fruits, flowers and young leaves on the feeding patterns of guerezas, seasonal changes in diet were analyzed (Fig. 3). We observed that the majority of the feeding time in the monkeys of the study group was dedicated to the feeding of young leaves throughout the study period; however, during certain times of the year, fruits/seeds accounted for over $45 \%$ of monthly feeding record. Monthly fruit availability was not significantly correlated with fruit-eating $(\mathrm{r}=0.42, P=0.069)$, flower-eating $(\mathrm{r}=0.42, P=0.052)$ and leaf-eating $(\mathrm{r}=0.32, P=0.086)$ activities. Alternatively, monthly flower availability was significantly correlated with flower-eating activity ( $\mathrm{rs}=0.57, P=0.004$ ) but not with fruit-eating (rs $=0.084, P=$ 0.665 ) and leaf-eating ( $\mathrm{rs}=0.31, P=0.213$ ) activities. In addition, monthly leaf availability was significantly correlated with fruit-eating $(\mathrm{r}=-0.42, P=0.044)$ and flower-eating $(\mathrm{r}=-0.52, P=0.011)$ activities but not with leaf activity $(\mathrm{r}=-0.32, P=$ 
0.089).

We observed that the young leaves of $C$. durandii were the most important food source for the study group in our site, and its feeding record on young leaves was much higher than that of the second and third most important food sources. The study group consumed $C$. durandii young leaves in each of the study months, ranging from $34.2 \%$ in February 2015 to $90.8 \%$ in April 2014. The monthly feeding record of C. durandii was not significantly correlated with monthly fruit $(\mathrm{r}=-0.15, P=0.866)$, flower $(\mathrm{r}=-0.08$, $P=0.692)$ and leaf availabilities $(\mathrm{r}=-0.28, \mathrm{P}=0.840)$.

The mean of the 29 monthly Shannon-Wiener indices of food species diversity $\left(H^{\prime}\right)$ was 1.37 (range: from 0.35 in April 2015 to 2.19 in February 2014). The best-fit model to explain the monthly dietary diversity included the leaf availability, and the second-best model was the null model (Table 3); the dietary diversity increased with the decreasing leaf availability (Fig. 4).

\section{Discussion}

In accordance with observations of previous studies on feeding behaviors of guerezas, we confirmed a high level of leaf-eating activity in the study group in general: Kalinzu Forest, Uganda, 87\% (this study); Kibale National Park, Uganda, 54\%-94\% (Harris and Chapman 2007; Oates 1977; Wasserman and Chapman 2003); Borena-Sayint National Park, Ethiopia: 73\% (Hussein et al. 2017); and Ituri, DR Congo, 58\% (Bocian 1997, but refer to Fashing 2011). However, this dietary pattern is contrary to those of other guereza populations that have been observed, such as a relatively low level of leaf-eating activity but a higher level of fruit-eating activity in Kakamega, Kenya (leaves, 48\%-57\%; fruits/seeds, 33\%-44\%) (Fashing 2001) and Dja Faunal Reserve, Cameroon (leaves, 36\%; fruits, 55\%) (Poulsen et al. 2002). Available dietary data indicate that the guereza, which is the most widely distributed species of the genus in Africa, is ecologically flexible and adapts to different local environmental conditions. Indeed, during the study period, fruit-eating activity accounted for $45 \%$ of monthly feeding records, indicating their dietary flexibility even in response to seasonal conditions. 
Moreover, we observed that the consumption of fruits and flowers in the study group significantly increased with the decrease in availability of leaf, but their fruit consumption did not significantly increase when fruit availability was high, suggesting that the tendency of choosing fruits is not strong. Additionally, the study group relied on the young leaves of $C$. durandii and fed heavily on them throughout the study period. Since the significant correlations between the leaf-eating of $C$. durandii and monthly leaf, fruit and flower availability were not detected, the operational definition of fallback foods, i.e., foods whose consumption is negatively correlated with the availability of preferred foods (Lambert and Rothman 2015; Marshall and Wrangham 2007), does not apply to this case. Nonetheless, a tendency shared by many groups of guerezas to heavily consume $C$. durandii leaves has been reported in Kibale National Park, Uganda, because of the nutrients in $C$. durandii leaves. These leaves are considered high-quality because of their high protein-to-fiber ratio (Chapman et al. 2003; Harris and Chapman 2007). Considering that they are nutrient-dense and are relatively abundant (easy to find and access), the study group may exhibit a preference for $C$. durandii leaves. Further evaluation of their dietary choices in terms of chemical and physical properties, depending on their digestive physiology and the availability of food resources (e.g., Chapman and Chapman 2002; Matsuda et al. 2017), is necessary in future studies.

From a range of 28 to 43 different food species that were reported to be consumed by other populations at Kakamega, Kibale National Park, and Ituri, the study group consumed a total of 31 food species (39 if we include the preliminary observation), which was within the specified range. However, the mean monthly $H^{\prime}$ of the study group (1.37) was lower than that of other populations in Kibale National Park (1.72), Ituri (1.90) and Kakamega (1.61 and 1.73), as compared with that reported by Fashing (2001). Considering the fact that the total number of plant species used as a food source by the study group was much lower than that described in the vegetation survey (68 species), we support Fashing (2001)'s statement that "guerezas appear to be adapted to feed on relatively few food species and to maintain a low dietary species diversity even in species-rich rain forest environments." 
Monthly dietary diversity increased as the number of available plants with young leaves decreased; it was noted that the effects of the availability of fruits and flowers were insignificant (Table 3). Much of the dietary diversity in the study group is seemingly attributable to the young leaf portion of their diet. Because the overall availability of young leaves declined during the study period, the guerezas were possibly forced to consume different species. This tendency of increased dietary diversity during periods when high-quality foods (i.e., young leaves and/or fruits) are scarce has also been reported in several colobine species like C. guereza (Fashing 2001), Nasalis larvatus (Matsuda et al. 2009; Yeager 1989), Presbytis entellus (Newton 1992), P. rubicunda (Davies 1991) and Trachypithecus francoisi (Zhou et al. 2006). Such relationships between dietary diversity and plant abundance/availability appear to be one of the general survival strategies of colobines.

In conclusion, the study group of guerezas in the Kalinzu Forest was highly folivorous and relied heavily on $C$. durandii leaves, possibly because of the high amounts these leaves being nutrient-dense and highly abundant in the study site, as observed elsewhere in Uganda. However, the study group also showed an increase $(45 \%)$ in the consumption of seeds and whole fruits in response to local environmental conditions, i.e., when the leaf availability decreased, indicating the dietary flexibility of guerezas. Given that we studied a single group during one time period, this study may not be representative of the typical dietary patterns of a species or population, even at a single site. However, though our detailed descriptive study based on the behavioural observation over 30 months would be useful to provide data for further comparative meta-analysis to understand the ecological flexibility of this species in different habitats.

\section{Acknowledgements}

We are grateful to the Uganda National Council for Science and Technology, the Uganda Forestry Department, and Uganda Wildlife Authority for permission to work in the Kalinzu Forest. Our appreciation goes to the research assistants and managers from this project, particularly, Mina Isaji, Hodaka Matsuo, Natsumi Aruga, Reiko Okano and Charles Lakwo because, without their a lot of assistances for accommodating and 
facilitating data collection for this project, it would not have been possible to conduct this study. We also thank Olivia Wanyana Maganyi of the Herbarium of Makerere University for their help in identification of plants and Yuri Oi and Nao Oi for their help in data entry work. This study was partly financed by the HOPE and Human Evolution Project of the Primate Research Institute, Kyoto University; JSPS KAKENHI (\#19H03308 to IM, \#25304019 to CH, \#16H02753 to TY, \#21255006 and \#25257409 to HI, \#24570257 to YT) and Strategic Young Researcher Overseas Visits Program for Accelerating Brain Circulation from JSPS (to H Hirai). All research was conducted in compliance with animal care regulations and applicable Uganda laws 


\section{References}

Bocian CM (1997) Niche separation of black-and-white colobus monkeys (Colobus angolensis and C. guereza) in the Ituri Forest. Ph. D. Ph. D. thesis, City University of New York, New York

Burnham KP, Anderson DR (2002) Model selection and multimodel inference: a practical information-theoretic approach, 2nd edn. Springer, Verlag

Campbell CJ, Fuentes A, MacKinnon KC, Bearder SK, Stumpf RM (2011) Primates in perspective. Oxford University Press, New York

Chapman CA, Chapman LJ (2002) Foraging challenges of red colobus monkeys: influence of nutrients and secondary compounds. Comparative biochemistry and physiology. Part A, Molecular \& integrative physiology 133:861-875. doi: 10.1016/s1095-6433(02)00209-x

Chapman CA, Chapman LJ, Rode KD, Hauck EM, McDowell LR (2003) Variation in the Nutritional Value of Primate Foods: Among Trees, Time Periods, and Areas. Int. J. Primatol. 24:317-333. doi: 10.1023/a:1023049200150

Chivers D (1994) Functional anatomy of the gastrointestinal tract. In: Davies A, Oates J (eds) Colobine monkeys: their ecology, behaviour and evolution. Cambridge University Press, Cambridge, pp 205-227

Clutton-Brock TH (1975) Feeding Behaviour of Red Colobus and Black and White Colobus in East Africa. Folia Primatol. 23:165-207. doi: 10.1159/000155671

Colwell RK (2013) EstimateS: Statistical estimation of species richness and shared species from samples, 9 edn

Davies G (1991) Seed-eating by red leaf monkeys (Presbytis rubicunda) in dipterocarp forest of northern borneo. Int. J. Primatol. 12:119-144. doi: 10.1007/bf02547577

Fashing PJ (2001) Feeding ecology of guerezas in the Kakamega forest, Kenya: the importance of Moraceae fruit in their diet. Int. J. Primatol. 22:579-609. doi: 10.1023/a:1010737601922

Fashing PJ (2011) African colobine monkeys: their behavior, ecology, and conservation. In: Campbell CJ, Fuentes A, MacKinnon KC, Bearder SK, Stumpf RM (eds) Primates in Perspective, 2nd edition edn. Oxford University Press, Oxford, pp 203-229

Hanya G, Tsuji Y, Grueter CC (2013) Fruiting and flushing phenology in Asian tropical and temperate forests: implications for primate ecology. Primates 54:101-110. doi: 10.1007/s10329-012-0341-3

Harris TR, Chapman CA (2007) Variation in diet and ranging of black and white colobus monkeys in Kibale National Park, Uganda. Primates 48:208-221. doi: 10.1007/s10329-006-0036-8

Hashimoto C, Furuichi T, Tashiro Y, Kimura D (1999) Vegetation of the Kalinzu Forest, Uganda: ordination of forest types using principal component analysis. African Study Monographs 20:229-239

Hemingway CA, Bynum N (2005) The influence of seasonality on primate diet and ranging. In: Brockman DK, van Schaik CP (eds) Seasonality in Primates, vol 57-104. Cambridge University Press, Cambridge

Holm S (1979) A simple sequentially rejective multiple test procedure. Scandinavian Journal of Statistics 6:65-70. doi: 10.2307/4615733

Hussein I, Afework B, Dereje Y (2017) Population structure and feeding ecology of Guereza (Colobus guereza) in Borena-Sayint National Park, northern Ethiopia. International Journal of Biodiversity and Conservation 9:323-333. doi: 10.5897/ijbc2017.1114

Kirkpatrick RC (2011) The Asian colobines: diversity among leaf-eating monkeys. In: Campbell CJ, Fuentes A, MacKinnon KC, Bearder SK, Stumpf RM (eds) Primates in Perspective, 2nd edition 
edn. Oxford University Press, Oxford, pp 189-202

Lambert JE, Rothman JM (2015) Fallback Foods, Optimal Diets, and Nutritional Targets: Primate Responses to Varying Food Availability and Quality. Annual Review of Anthropology 44:493-512. doi: 10.1146/annurev-anthro-102313-025928

Marshall AJ, Wrangham RW (2007) Evolutionary consequences of fallback foods. Int. J. Primatol. 28:1219-1235. doi: 10.1007/s10764-007-9218-5

Matsuda I, Chapman CA, Clauss M (2019) Colobine forestomach anatomy and diet. J. Morphol. 280:1608-1616. doi: 10.1002/jmor.21052

Matsuda I, Clauss M, Tuuga A, Sugau J, Hanya G, Yumoto T, Bernard H, Hummel J (2017) Factors affecting leaf selection by foregut-fermenting proboscis monkeys: new insight from in vitro digestibility and toughness of leaves. Scientific reports 7:42774. doi: 10.1038/srep42774

Matsuda I, Tuuga A, Higashi S (2009) The feeding ecology and activity budget of proboscis monkeys. Am. J. Primatol. 71:478-492. doi: 10.1002/ajp.20677

Newton P (1992) Feeding and ranging patterns of forest hanuman langurs (Presbytis entellus). Int. J. Primatol. 13:245-285. doi: 10.1007/bf02547816

Oates JF (1977) The Guereza and Its Food. In: Clutton-Brock TH (ed) Primate Ecology: Studies of Feeding and Ranging Behaviour in Lemurs, Monkeys and Apes. Academic Press, New York, pp 276-319

Oates JF, Davies AG, delson E (1994) The diversity of living colobines. In: Davies AG, Oates JF (eds) Colobine monkeys: their ecology, behaviour and evolution. Cambridege University Press, Cambridge, pp 45-73

Pielou EC (1966) Shannon's formula as a measure of specific diversity: its use and misuses. Am. Nat. 104:463-465

Poulsen JR, Clark CJ, Connor EF, Smith TB (2002) Differential Resource Use by Primates and Hornbills: Implications for Seed Dispersal. Ecology 83:228-240. doi: 10.1890/0012-9658(2002)083[0228:drubpa]2.0.co;2

Quinn GP, Keough MJ (2002) Experimental design and data analysis for biologists. Cambridge University Press, Cambridge

R-Core-Development-Team (2019) R: a language and environment for statistical computing. Foundation for Statistical Computing, Vienna

Wasserman MD, Chapman CA (2003) Determinants of colobine monkey abundance: the importance of food energy, protein and fibre content. J. Anim. Ecol. 72:650-659. doi: 10.1046/j.1365-2656.2003.00736.x

Yeager CP (1989) Feeding ecology of the proboscis monkey (Nasalis larvatus). Int. J. Primatol. 10:497-530. doi: 10.1007/bf02739363

Zhou Q, Wei F, Li M, Huang C, Luo B (2006) Diet and Food Choice of Trachypithecus francoisi in the Nonggang Nature Reserve, China. Int. J. Primatol. 27:1441-1460. doi: 10.1007/s10764-006-9082-8

Zinner D, Tesfaye D, Stenseth NC, Bekele A, Mekonnen A, Doeschner S, Atickem A, Roos C (2019) Is Colobus guereza gallarum a valid endemic Ethiopian taxon? Primate Biology 6:7-16. doi: $10.5194 / \mathrm{pb}-6-7-2019$ 


\section{Table and Figure legends}

Table 1. Floral composition along the 12 trails. The total distance of the trails was 4.7 $\mathrm{km}$, and the vegetation survey was conducted for trees with a DBH of $\geq 10 \mathrm{~cm}$ and vines with a diameter of $\geq 5 \mathrm{~cm}$, located $\leq 1.5 \mathrm{~m}$ from the trail (total survey area $=$ $1.41 \mathrm{ha})$.

Table 2. Food items and parts of each item consumed by the study group from November 2013 to April 2016.

Table 3. Summary of model selection using linear models to investigate whether the dietary diversity $\left(H^{\prime}\right)$ of the study group was affected by the availability of fruits, flowers, and young leaves.

Figure 1. Species accumulation curves (species vs. area curves) of the study site covering the survey area of 1.41 ha. Error bars indicate standard deviation. We performed 100 randomizations using the data of the number of tree species with a DBH of $\geq 10 \mathrm{~cm}$ and vine species with a diameter of $\geq 5 \mathrm{~cm}$ at subplots of $3 \mathrm{~m} \times 50 \mathrm{~m}$ and used EstimateS ver. 9 (Colwell 2013) to produce the curves.

Figure 2. Young leafing, fruiting, and flowering phenology between November 2013 and April 2016. Values indicate ratios of the monthly number of counted plants to young leaves, fruits and flowers; the presence or absence of observed fruits and flowers was examined for each plant, but the presence or absence of young leaves was examined using abundance scores (see Methods section). Square = all plants; circle $=$ guereza's food species only.

Figure 3. Seasonal changes in the diet composition of the study group; values indicate the percentage of monthly feeding time spent on each food category.

Figure 4. Relationship between the monthly availability of young leaves and dietary 
bioRxiv preprint doi: https://doi.org/10.1101/832451; this version posted November 6,2019 . The copyright holder for this preprint (which was not certified by peer review) is the author/funder, who has granted bioRxiv a license to display the preprint in perpetuity. It is made available under aCC-BY-NC-ND 4.0 International license.

diversity. 
bioRxiv preprint doi: https://doi.org/10.1101/832451; this version posted November 6,2019 . The copyright holder for this preprint (which was not certified by peer review) is the author/funder, who has granted bioRxiv a license to display the preprint in perpetuity. It is made available under aCC-BY-NC-ND 4.0 International license.

Table 1. Floral composition along the 12 trails. The total distance of the trails was 4.7 $\mathrm{km}$, and the vegetation survey was conducted for trees with a DBH of $\geq 10 \mathrm{~cm}$ and vines with a diameter of $\geq 5 \mathrm{~cm}$, located at $\leq 1.5 \mathrm{~m}$ from the trail (total survey area $=1.41 \mathrm{ha}$ ).

\begin{tabular}{|c|c|c|c|c|c|c|c|c|c|c|c|c|c|c|c|}
\hline \multirow[t]{2}{*}{ Family } & \multirow[t]{2}{*}{ Genus \& Species } & \multirow[t]{2}{*}{ Sort } & \multicolumn{12}{|c|}{ Trail ID and number of plants } & \multirow[b]{2}{*}{ Total } \\
\hline & & & $\mathrm{T} 1$ & $\mathrm{~T} 2$ & $\mathrm{~T} 3$ & $\mathrm{~T} 4$ & T5 & T6 & $\mathrm{T} 7$ & $\mathrm{~T} 8$ & T9 & T10 & T11 & $\mathrm{T} 12$ & \\
\hline Anacardiaceae & Pseudospondias microcarpa & Tree & & & & 1 & & & 3 & & 1 & 4 & & & 9 \\
\hline Anacardiaceae & Trichoscypha submontana & Tree & & & & 1 & & & & 1 & 1 & 1 & & 1 & 5 \\
\hline Apocynaceae & Funtumia africana & Tree & 9 & 13 & 21 & 33 & 11 & 9 & 12 & 10 & 10 & 5 & 10 & 41 & 184 \\
\hline Apocynaceae & Tabernaemontana holstii & Tree & 3 & & 1 & 1 & 1 & & 1 & 2 & 1 & & 2 & 1 & 13 \\
\hline Apocynaceae & Landolphia buchananii & Vine & & & & & & & & & 4 & & & & 4 \\
\hline Apocynaceae & Saba comorensis & Vine & & 1 & & & & & & & & 2 & & & 3 \\
\hline Apocynaceae & Landolphia dawei & Vine & & & & & & & & & & & & 1 & $\mathbf{1}$ \\
\hline Apocynaceae & Pleiocarpa pycnantha & Tree & & & & & & 1 & & & & & & & 1 \\
\hline Asteraceae & Vernonia conferta & Tree & & & 1 & & & & 1 & & & & & & 2 \\
\hline Bignoniaceae & Markhamia lutea & Tree & & 1 & & 1 & & & & & & & 2 & 7 & 11 \\
\hline Boraginaceae & Cordia africana & Tree & & & & & & & 1 & & 1 & & & & 2 \\
\hline Cannabaceae & Celtis durandii & Tree & 2 & 7 & 5 & 10 & 5 & & 11 & 8 & 13 & 3 & 6 & 10 & 80 \\
\hline Cannabaceae & Trema orientalis & Tree & & 4 & & 2 & & & & 1 & 2 & & 1 & & 10 \\
\hline Celastraceae & Maytenus acuminata & Tree & & 1 & & & & & & & & & & & 1 \\
\hline Chrysobalanaceae & Parinari excelsa & Tree & & 1 & & 1 & & & 2 & & & & & & 4 \\
\hline Clusiaceae & Symphonia globulifera & Tree & & & 4 & & 1 & 1 & & & & & 1 & 2 & 9 \\
\hline Connaraceae & Agelaea pentagyna & Vine & & & 3 & & & & & & 1 & 1 & & 3 & 8 \\
\hline Ebenaceae & Diospyros abyssinica & Tree & & & & 1 & & & & & & & & 2 & 3 \\
\hline Euphorbiaceae & Phyllanthus discoideus & Tree & 6 & & & 6 & & 2 & & 2 & 2 & 3 & 1 & 12 & 34 \\
\hline Euphorbiaceae & Macaranga schweifurthii & Tree & & 1 & 4 & & & 2 & 2 & 5 & & 2 & & 5 & 21 \\
\hline Euphorbiaceae & Macaranga kilimandscharica & Tree & & 1 & & 4 & & 1 & 1 & 2 & 1 & & 3 & & 13 \\
\hline Euphorbiaceae & Sapium ellipticum & Tree & & & 1 & & & 1 & 1 & 2 & & & & 3 & 8 \\
\hline Euphorbiaceae & Alchornea hirtella & Tree & & 2 & & 1 & & & & & & & & & 3 \\
\hline Euphorbiaceae & Suregada procera & Tree & & & & & 1 & & & & & & & & 1 \\
\hline Fabaceae & Newtonia buchananii & Tree & 1 & 1 & 1 & 1 & & & 6 & 1 & 5 & 4 & 2 & 4 & 26 \\
\hline Flacourtiaceae & Dovyalis sp. & Tree & & & & & & & & & & & & 2 & 2 \\
\hline Hypericaceae & Harungana madagascariensis & Tree & & & & & & 1 & & & & & & & 1 \\
\hline Lamiaceae & Vitex ferruginea & Tree & & & & & & & & & & & & 1 & $\mathbf{1}$ \\
\hline Lauraceae & Beilschmiedia ugandensis & Tree & 1 & & & 2 & & & 1 & & 2 & 1 & 2 & & 9 \\
\hline Malpighiaceae & Flabellariopsis acuminata & Vine & & & & & & & & & & 1 & & & 1 \\
\hline Meliaceae & Carapa procera & Tree & 5 & 9 & 9 & 16 & 8 & 4 & 4 & 16 & 5 & 9 & 13 & 22 & 120 \\
\hline Meliaceae & Entandrophragma sp. & Tree & & & 1 & 1 & & 1 & & & & 1 & & & 4 \\
\hline Meliaceae & Trichilia volkensii & Tree & & & & & & & & 2 & & & & & 2 \\
\hline Monimiaceae & Xymalos monospora & Tree & 1 & 1 & & & & & & & & & & & 2 \\
\hline Moraceae & Ficus sur & Tree & 2 & & 4 & 2 & 3 & & 3 & 3 & & 3 & & 10 & 30 \\
\hline Moraceae & Ficus saussureana & Tree & & 3 & & 1 & & & 1 & 1 & & 4 & 1 & 1 & 12 \\
\hline Moraceae & Antiaris toxicaria & Tree & & & & 1 & & & & & & 1 & & 2 & 4 \\
\hline Moraceae & Ficus vallis-choudae & Tree & & & & & & & & & & & & 4 & 4 \\
\hline Moraceae & Bosquiea phoberos & Tree & & & & 1 & & & & & & 1 & 1 & & 3 \\
\hline Moraceae & Ficus sansibarica & Tree & & & & 1 & & & & & & & & 1 & 2 \\
\hline Moraceae & Ficus bubu & Tree & & & & & & & & & & 1 & & & $\mathbf{1}$ \\
\hline Moraceae & Ficus conraii & Vine & & & & & 1 & & & & & & & & 1 \\
\hline Moraceae & Ficus natalensis & Tree & & & & 1 & & & & & & & & & 1 \\
\hline Moraceae & Ficus pseudomangifera & Tree & & & & & & 1 & & & & & & & 1 \\
\hline Moraceae & Ficus thonningii & Tree & 1 & & & & & & & & & & & & 1 \\
\hline Myrtaceae & Syzygium guineense & Tree & & & 2 & 2 & & 2 & 1 & & 1 & 5 & & 3 & 16 \\
\hline Olacaceae & Strombosia scheffleri & Tree & 2 & 7 & 6 & 16 & 6 & 6 & 14 & 2 & 6 & 9 & 8 & 19 & 101 \\
\hline Oleaceae & Linociera johnsonii & Tree & & & & 1 & & & & & & 4 & & 1 & 6 \\
\hline Piperaceae & Piper capense & Vine & & 1 & 1 & 1 & 3 & 1 & & & & & & & 7 \\
\hline Rhamnaceae & Gouania longispicata & Vine & & & & & & & & & & 1 & & & 1 \\
\hline Rhizophoraceae & Cassipourea sp. & Tree & 1 & & 1 & & & & & 1 & & 2 & 2 & 1 & 8 \\
\hline Rosaceae & Prunus africana & Tree & & & & & & & & & 1 & & & 5 & 6 \\
\hline Rubiaceae & Craterispermum laurinum & Tree & 1 & & 3 & 8 & 2 & 4 & 2 & 3 & 3 & 2 & 4 & 6 & 38 \\
\hline Rubiaceae & Oxyanthus speciosus & Tree & 2 & 2 & 1 & 4 & 2 & 2 & 3 & & 6 & 2 & 1 & & 25 \\
\hline Rubiaceae & Dictyandra sp. & Tree & & 1 & & & & 1 & 4 & 1 & 5 & 2 & & 2 & 16 \\
\hline Rubiaceae & Mitragyna stipulosa & Tree & & & 1 & & & 2 & & 2 & & 2 & 6 & & 13 \\
\hline Rubiaceae & Rothmannia longiflora & Tree & & 1 & & & & & 1 & & & & & & 2 \\
\hline Rutaceae & Fagaropsis angolensis & Tree & & 1 & 1 & 3 & 10 & & 1 & 1 & 2 & 1 & 1 & 2 & 23 \\
\hline Rutaceae & Teclea nobilis & Tree & & & & 2 & & & & & & & & 6 & 8 \\
\hline Rutaceae & Zanthoxylum rubescens & Tree & & & & & & & & & & & & 1 & 1 \\
\hline Sapindaceae & Blighia unijugata & Tree & & & & & 1 & & & & & & 1 & 1 & 3 \\
\hline Sapotaceae & Chrysophyllum albidum & Tree & & 1 & & 1 & & & 1 & & & & & & 3 \\
\hline Sapotaceae & Bequaertiodendron oblanceolatum & Tree & & & & 1 & & & & & & & & & 1 \\
\hline Urticaceae & Musanga leo-errerae & Tree & 8 & 2 & 2 & 1 & 6 & 6 & & 11 & 6 & 2 & 9 & 1 & 54 \\
\hline Urticaceae & Myrianthus holstii & Tree & & 1 & 2 & & & & & & & 1 & & & 4 \\
\hline Violaceae & Rinorea ilicifolia & Tree & & & & & & & & & & & & 1 & 1 \\
\hline \multirow[t]{2}{*}{ Vitaceae } & Cissusproducta sp. & Vine & & & & & & & & & & 1 & & & 1 \\
\hline & & Total & 45 & 63 & 75 & 129 & 61 & 48 & 77 & 77 & 79 & 81 & 77 & 184 & 996 \\
\hline
\end{tabular}


Table 2. Food items and parts of each item consumed by the study group from November 2013 to April 2016.

*Consumed by guerezas when they were habituated. This was not observed during the study period.

\begin{tabular}{|c|c|c|c|c|c|c|c|c|c|c|c|c|c|c|c|c|c|c|c|c|c|c|c|}
\hline & \multirow{2}{*}{ Species } & \multicolumn{2}{|c|}{2013} & \multicolumn{11}{|c|}{2014} & \multicolumn{9}{|c|}{2015} \\
\hline & & $\mathrm{N}$ & $\mathrm{D}$ & $\mathrm{J}$ & $\mathrm{F}$ & $\mathrm{M}$ & & $\mathrm{M}$ & $\mathrm{J}$ & $\mathrm{J}$ & $\mathrm{A}$ & $\mathrm{s}$ & $\mathrm{O}$ & $\mathrm{N} \quad \mathrm{D}$ & $\mathrm{J}$ & $\mathrm{F}$ & $\mathrm{M}$ & $\mathrm{A}$ & $\mathrm{M}$ & $\mathrm{J}$ & $\mathrm{J}$ & $\mathrm{A}$ & $\mathrm{s}$ \\
\hline Apocynaceae & Rauvolfia caffra & & & & & & & & & & & & & & & & & & & & & & \\
\hline Apocynaceae & Tabernaemontana holstii & & & & $\mathrm{Yl}$ & & & & & & & & & & & $\mathrm{Y} 1$ & & & & & $\mathrm{Yl}$ & & \\
\hline Apocynaceae & Funtumia africana $*$ & & & & & & & & & & & & & & & & & & & & & & \\
\hline Asteraceae & Vernonia conferta & & & & $\mathrm{Yl}$ & $\mathrm{Yl}$ & & & $\mathrm{Yl}$ & & & & $\mathrm{Yl}_{1}$ & & $\mathrm{Yl}$ & & $\mathrm{Yl}$ & & & $\mathrm{Yl}$ & $\mathrm{Yl}_{1}$ & & \\
\hline Bignoniaceae & Markhamia lutea & $\mathrm{Y} 1$ & $\mathrm{Yl}$ & $\mathrm{Y}_{1}$ & $\mathrm{Yl}$ & $\mathrm{YI}$ & & & Y1 & $\mathrm{Yl}$ & $\mathrm{Yl}, \mathrm{Fl}$ & & & & $\mathrm{Yl}$ & & $\mathrm{Yl}$ & $\mathrm{Yl}$ & & $\mathrm{Yl}$ & $\mathrm{Yl}$ & $\mathrm{Yl}$ & \\
\hline Boraginaceae & Cordia africana & & & & & & & $\mathrm{Y1}$ & & & & $\mathrm{Yl}$ & & & & & & & & & $\mathrm{Yl}$ & $\mathrm{Yl}$ & \\
\hline Cannabaceae & Celtis durandii & $\mathrm{Ml}, \mathrm{Yl}, \mathrm{Se}$ & $\mathrm{Yl}, \mathrm{Se}$ & $\mathrm{Ml}, \mathrm{Yl}, \mathrm{Se}$ & $\mathrm{Ml}, \mathrm{Yl}$ & $\mathrm{Y1}$ & $\mathrm{Y1}$ & $\mathrm{Y} 1$ & $\mathrm{YI}$ & $\mathrm{Yl}$ & $\mathrm{Yl}, \mathrm{Fl}$ & $\mathrm{Yl}, \mathrm{Fl}, \mathrm{Se}$ & YI & YI & Ml, Yl, Rfr, Unfr & Yml, Yl, Rfr & Tl, Fl, Rfr & $\mathrm{Yl}, \mathrm{Rfr}$ & Yl, Rfr & Ml, Yl & $\mathrm{Ml}, \mathrm{Yl}, \mathrm{Rfr}$ & $\mathrm{Yl}, \mathrm{F}, \mathrm{Rfr}$ & $\mathrm{Yl}, \mathrm{F}, \mathrm{RI}$ \\
\hline Cannabaceae & Trema orientalis ${ }^{*}$ & & & & & & & & & & & & & & & & & & & & & & \\
\hline Capparaceae & Ritchiea albersii & & & & & & & & & & $\mathrm{Yl}$ & & & & $\mathrm{Yl}$ & & & & & & & $\mathrm{Yl}, \mathrm{Fl}$ & \\
\hline \multicolumn{24}{|c|}{ Chrysobalanacear Parinari excelsa ${ }^{*}$} \\
\hline Clusiaceae & Symphonia globulifera & & & & & & 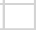 & 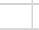 & & & & & & & Ml & & & & & & & & \\
\hline Connaraceae & Agelaea pentagyna & $\mathrm{Y} 1$ & & & & & 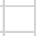 & 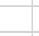 & & & & & & & & & & & & & & & \\
\hline Cornaceae & Alangium chinense & & & & & & & & & & & & & & & & & & & $\mathrm{Yl}$ & & & \\
\hline Euphorbiaceae & Macaranga kilimandscharica & $\mathrm{Yl}$ & $\mathrm{Y} 1$ & $\mathrm{YI}$ & $\mathrm{Yl}$ & & & $\mathrm{Y1}$ & & & $\mathrm{Y} 1$ & & & & & & & & & & & & \\
\hline Euphorbiaceae & Sapium ellipticum & Se & Se & & $\mathrm{Yl}$ & $\mathrm{YI}$ & Se & Se & Se & & $\mathrm{Yl}$ & Yl, Unfr & ML, Yl, Rfr, Unfr, Se & Yl, Rfr & $\mathrm{Yl}, \mathrm{Rfr}$ & $\mathrm{Yl}, \mathrm{Se}$ & & $\mathrm{YI}$ & & $\mathrm{Yl}$ & Yl & Ml & $\mathrm{yl}, \mathrm{Rfr}$ \\
\hline Fabaceae & Newtonia buchananii & & & & $\mathrm{Yl}$ & $\mathrm{Yl}$ & & & $\mathrm{Yl}$ & $\mathrm{Yl}$ & & & & & & & & & & & & & \\
\hline Lauraceae & Persea americana & & & & & & & & & & & $\mathrm{Yl}$ & & & & & & & & & & & \\
\hline Malpighiaceae & Flabellariopsis acuminata & Se & Se & $\mathrm{Se}$ & Se & & & & $\mathrm{Se}$ & $\mathrm{Yl}, \mathrm{Se}$ & $\mathrm{Se}$ & & & & & & & & & $\mathrm{Se}$ & $\mathrm{Se}$ & & \\
\hline Meliaceae & Carapa procera & & & & $\mathrm{Ba}$ & Rfr, Ba & & Ва & & $\mathrm{Ba}$ & $\mathrm{Ba}$ & Ва & & & $\mathrm{Yl}, \mathrm{Ba}$ & Ва & ва & & Ва & & $\mathrm{Yl}, \mathrm{Ba}$ & Ва & Ва \\
\hline Moraceae & Ficus bubu & & & & & & & & & & & & & & & & & Se & & & & & \\
\hline Moraceae & Ficus natalensis & & & & $\mathrm{Yl}$ & & $\mathrm{Y} 1$ & 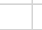 & Rfr & $\mathrm{Yl}$ & $\mathrm{Yl}$ & & & & $\mathrm{Yl}$ & $\mathrm{YI}$ & $\mathrm{YI}$ & YI & YI & $\mathrm{Yl}$ & & & \\
\hline Moraceae & Ficus sansibarica & & & & & & & 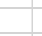 & & & & & & & $\mathrm{Yl}$ & & & & & & & & \\
\hline Moraceae & Ficus saussureana* & & & & & & & 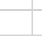 & & & & & & & & & & & & & & & \\
\hline Moraceae & Ficus spp** & & & & & & & & & & & & & & & & & & & & & & \\
\hline Myrtaceae & Eucalyptus grandis & & & & Ва & & & & & & & & & & & & & & & & & & \\
\hline Myrtaceae & Syzygium guineense & $\mathrm{YI}$ & $\mathrm{Yl}$ & $\mathrm{Yl}, \mathrm{Se}$ & $\mathrm{Yl}$ & $\mathrm{Y1}$ & & $\mathrm{Yl}$ & Y1 & $\mathrm{Yl}$ & $\mathrm{Yl}$ & & $\mathrm{YI}$ & Y1 & $\mathrm{YI}$ & $\mathrm{Y1}$ & $\mathrm{Yl}, \mathrm{Fl}$ & & & $\mathrm{Y}_{1}$ & $\mathrm{YI}$ & Yl, Unfr, Rfr & \\
\hline Olacaceae & Strombosia scheffleri & Unfr & & & $\mathrm{Yl}$ & $\mathrm{Y1}$ & & $\mathrm{Yl}$ & $\mathrm{Y1}$ & $\mathrm{Yl}$ & & $\mathrm{Yl}$ & $\mathrm{Yl}, \mathrm{Rfr}$ & $\mathrm{Yl}, \mathrm{Rfr}$ & $\mathrm{Yl}$ & $\mathrm{Yl}$ & $\mathrm{Y1}$ & & YI & $\mathrm{Yl}$ & $\mathrm{Yl}$ & $\mathrm{Yl}$ & \\
\hline Piperaceae & Piper capense & & & & & $\mathrm{Yl}$ & $\mathrm{Yl}$ & & Yl, Rfr & $\mathrm{Yl}$ & & & & & $\mathrm{Yl}$ & $\mathrm{Yl}$ & & & & & $\mathrm{Yl}$ & $\mathrm{Yl}$ & \\
\hline $\begin{array}{l}\text { Piperaceae } \\
\text { Perace }\end{array}$ & $\begin{array}{l}\text { Piper guineense } \\
\text { Pinse }\end{array}$ & & & & & & & & & & & Rfr & & & & & $\mathrm{Yl}$ & & & & & Rfr & \\
\hline Rhamnaceae & Gouania longispicata & & $\mathrm{Yl}$ & $\mathrm{Yl}, \mathrm{Fl}$ & $\mathrm{Yl}, \mathrm{Rfr}$ & & & & $\mathrm{Yl}$ & $\mathrm{Yl}, \mathrm{Fl}$ & $\mathrm{Y} 1$ & & $\mathrm{Yl}$ & $\mathrm{Y} 1$ & $\mathrm{Yl}$ & $\mathrm{Y1}$ & $\mathrm{Yl}$ & & $\mathrm{Yl}$ & $\mathrm{Yl}$ & $\mathrm{Yl}$ & $\mathrm{Yl}$ & \\
\hline Rhizophoraceae & Cassipourea sp. & $\mathrm{Yl}$ & $\mathrm{Yl}$ & & & & & & $\mathrm{YI}$ & $\mathrm{Yl}$ & & & & $\mathrm{YI}$ & & $\mathrm{Yl}$ & & $\mathrm{Yl}$ & & & & & \\
\hline Rosaceae & Prunus africana & $\mathrm{Yl}, \mathrm{Se}$ & $\mathrm{Yl}$ & $\mathrm{Yl}$ & $\mathrm{Yl}$ & $\mathrm{YI}$ & $\mathrm{Y} 1$ & $\mathrm{Yl}$ & $\mathrm{Yl}$ & $\mathrm{Yl}$ & $\mathrm{Ml}, \mathrm{Y1}$ & $\mathrm{Yl}$, Unfr & $\mathrm{Yl}$ & $\mathrm{Y1}$ & $\mathrm{Yl}$ & $\mathrm{Yl}, \mathrm{Rfr}$ & $\mathrm{Yl}, \mathrm{Rfr}$ & $\mathrm{Yl}$ & $\mathrm{Yl}$ & $\mathrm{Yl}$ & $\mathrm{Yl}$ & $\mathrm{Ml}, \mathrm{Yl}$ & $\mathrm{YI}$ \\
\hline Rubiaceae & Vangueria apiculata & $\mathrm{Yl}$ & & & $\mathrm{Yl}$ & & & & & & & & & & & & & & & & & & \\
\hline Rubiaceae & Mitragyna stipulosa* & & & & & & & & & & & & & & & & & & & & & & \\
\hline Rubiaceae & Oxyanthus speciosus* & & & & & & & & & & & & & & & & & & & & & & \\
\hline Rutaceae & Fagaropsi & $\mathrm{Y} 1$ & $\mathrm{Yl}$ & $\mathrm{Y1}$ & $\mathrm{Yl}$ & $\mathrm{YI}$ & $\mathrm{Yl}$ & $\mathrm{Yl}$ & $\mathrm{Y1}$ & & $\mathrm{Yl}$ & & $\mathrm{Yl}$ & $\mathrm{Yl}$ & $\mathrm{Yl}$ & $\mathrm{Y1}$ & $\mathrm{Yl}$ & $\mathrm{Yl}$ & $\mathrm{Y1}$ & $\mathrm{Yl}$ & $\mathrm{Yl}$ & $\mathrm{Yl}$ & $\mathrm{Y} 1$ \\
\hline Sapindaceae & Blighia unijugata & & & & & & & $\mathrm{Yl}$ & $\mathrm{Yl}, \mathrm{Fl}$ & $\mathrm{Fl}$ & & & & & & & & & & & & & \\
\hline Urticaceae & Musanga leo-errerae & $\mathrm{Fl}$ & & & Rfr & Rfr & & Rfr & Rfr & $\mathrm{Yl}$ & & & & & & $\mathrm{Yl}, \mathrm{Rfr}$ & Rfr & & & Rfr & & Rfr & \\
\hline \multirow[t]{4}{*}{ Urticaceae } & Myrianthus holstii & & & Y1 & $\mathrm{Yl}$ & $\mathrm{Yl}$ & & $\mathrm{Y} 1$ & & $\mathrm{Yl}$ & $\mathrm{Yl}$ & & & & $\mathrm{Yl}$ & $\mathrm{Yl}$ & & & & & & & \\
\hline & Soil & & & & So & & So & & So & & So & So & So & & So & So & & & So & So & & & So \\
\hline & Unknown 1 & & & & $\mathrm{Yl}$ & & & & & & & & & & & & & & & & & & \\
\hline & Unknown & $\mathrm{Yl}$ & & & $\mathrm{Yl}$ & $\mathrm{YI}$ & & & $\mathrm{Yl}$ & $\mathrm{Yl}$ & & & & & $\mathrm{Yl}$ & $\mathrm{Yl}$ & & $\mathrm{Yl}$ & $\mathrm{Yl}$ & & $\mathrm{Yl}$ & & \\
\hline
\end{tabular}


Table 3. Summary of model selection using linear models to investigate whether the dietary diversity $\left(H^{\prime}\right)$ of the study group was affected by the availability of fruits, flowers, and young leaves.

\begin{tabular}{ccccccccc}
\hline Intercept & $\begin{array}{c}\text { Fruit } \\
\text { availability }\end{array}$ & $\begin{array}{c}\text { Flower } \\
\text { availability }\end{array}$ & $\begin{array}{c}\text { Young leaf } \\
\text { availability }\end{array}$ & df & $\begin{array}{c}\text { Log- } \\
\text { likelihood }\end{array}$ & AICc & $\Delta$-AICc & Weight \\
\hline 2.7 & & & -1.1 & 3.0 & -13.8 & 34.5 & 0.0 & 0.3 \\
1.4 & & & & 2.0 & -15.2 & 34.9 & 0.4 & 0.3 \\
2.9 & & 2.9 & -1.4 & 4.0 & -13.3 & 36.3 & 1.8 & 0.1 \\
2.7 & 2.4 & & -1.3 & 4.0 & -13.4 & 36.5 & 2.0 & 0.1 \\
1.3 & 0.4 & & & 3.0 & -15.2 & 37.3 & 2.8 & 0.1 \\
1.4 & & -0.1 & & 3.0 & -15.2 & 37.3 & 2.9 & 0.1 \\
2.8 & 1.7 & 2.3 & -1.5 & 5.0 & -13.1 & 38.9 & 4.4 & 0.0 \\
1.3 & 0.6 & -0.3 & & 4.0 & -15.2 & 40.0 & 5.5 & 0.0 \\
\hline
\end{tabular}




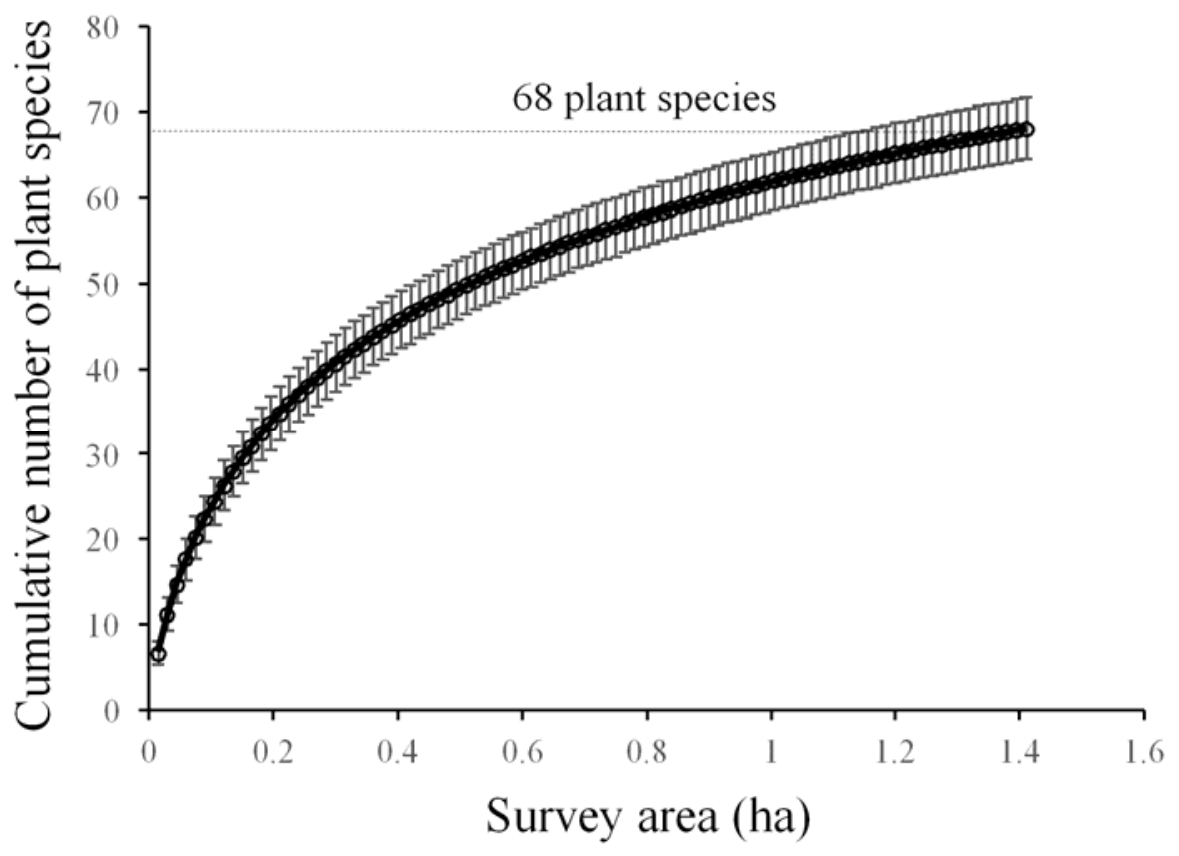

Figure 1. Species accumulation curves (species vs. area curves) of the study site covering the survey area of 1.41 ha. Error bars indicate standard deviation. We performed 100 randomizations using the data of the number of tree species with a DBH of $\geq 10 \mathrm{~cm}$ and vine species with a diameter of $\geq 5 \mathrm{~cm}$ at subplots of $3 \mathrm{~m} \times 50 \mathrm{~m}$ and used EstimateS ver. 9 (Colwell 2013) to produce the curves. 


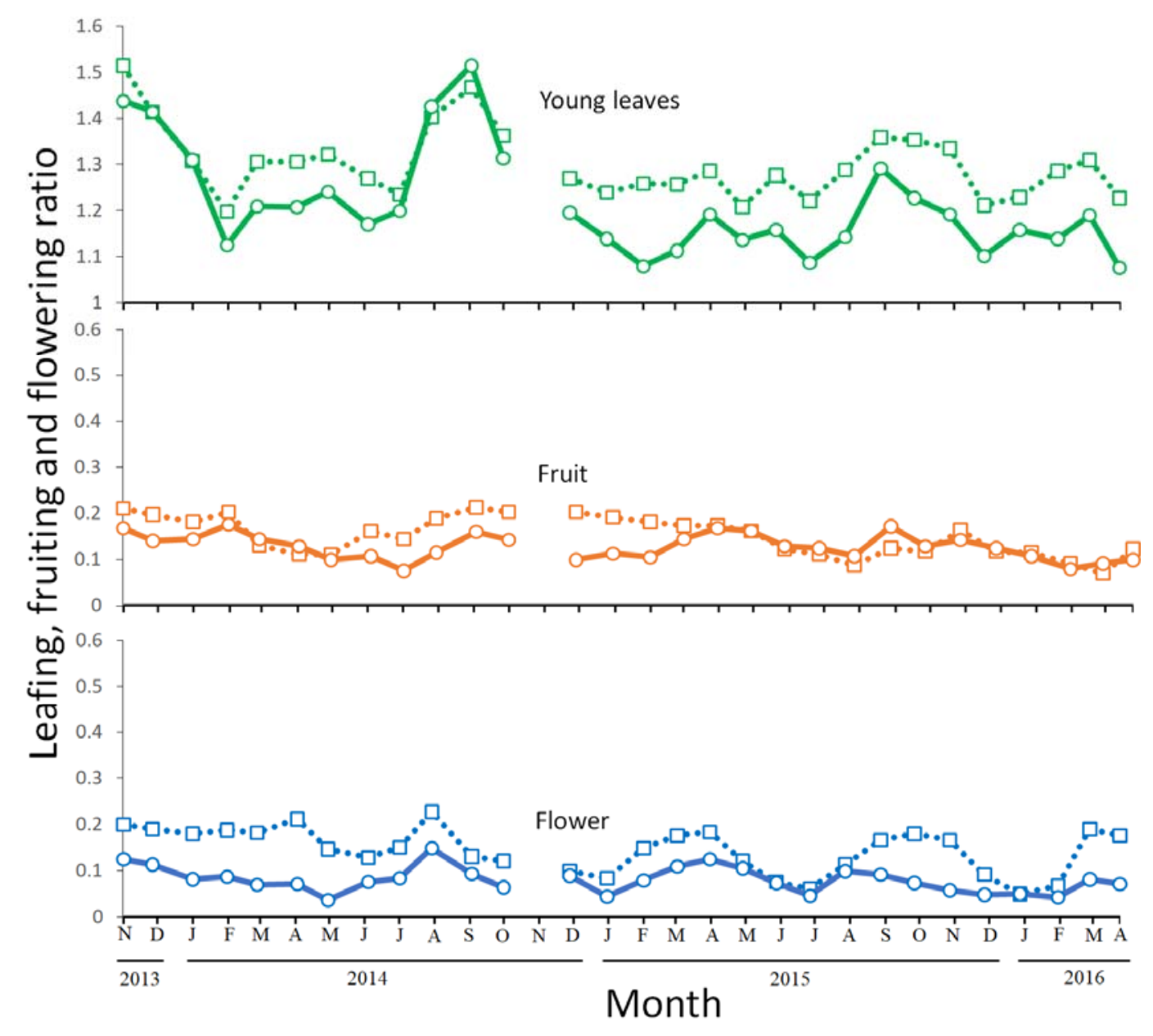

Figure 2. Young leafing, fruiting, and flowering phenology between November 2013 and April 2016. Values indicate ratios of the monthly number of counted plants to young leaves, fruits, and flowers; the presence or absence of observed fruits and flowers was examined for each plant, but the presence or absence of young leaves was examined using abundance scores (see Methods section). Square = all plants; circle $=$ guereza's food species only. 
bioRxiv preprint doi: https://doi.org/10.1101/832451; this version posted November 6,2019 . The copyright holder for this preprint (which was not certified by peer review) is the author/funder, who has granted bioRxiv a license to display the preprint in perpetuity. It is made available under aCC-BY-NC-ND 4.0 International license.

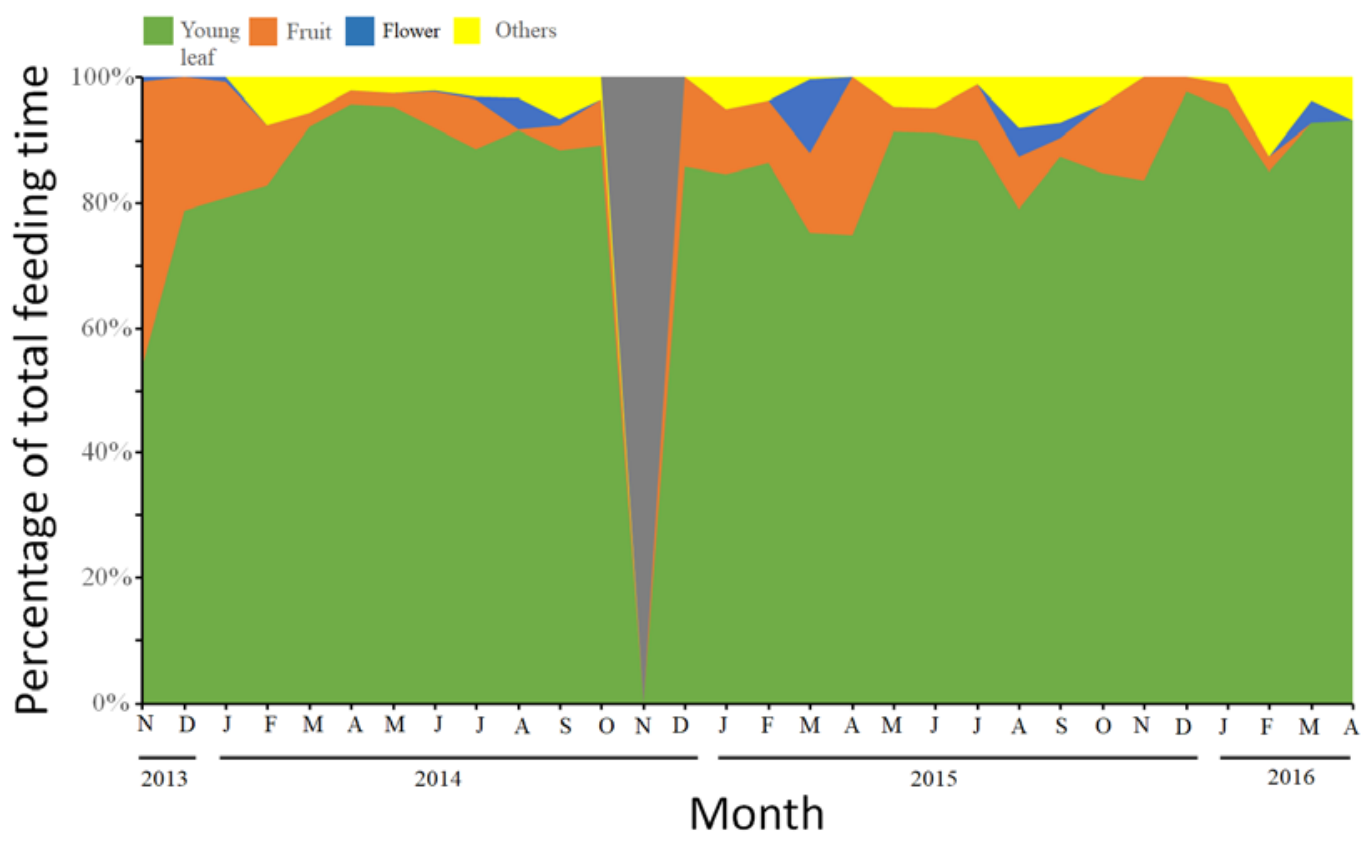

Figure 3. Seasonal changes in the diet composition of the study group; values indicate the percentage of monthly feeding time spent on each food category. 
bioRxiv preprint doi: https://doi.org/10.1101/832451; this version posted November 6 , 2019. The copyright holder for this preprint (which was not certified by peer review) is the author/funder, who has granted bioRxiv a license to display the preprint in perpetuity. It is made available under aCC-BY-NC-ND 4.0 International license.

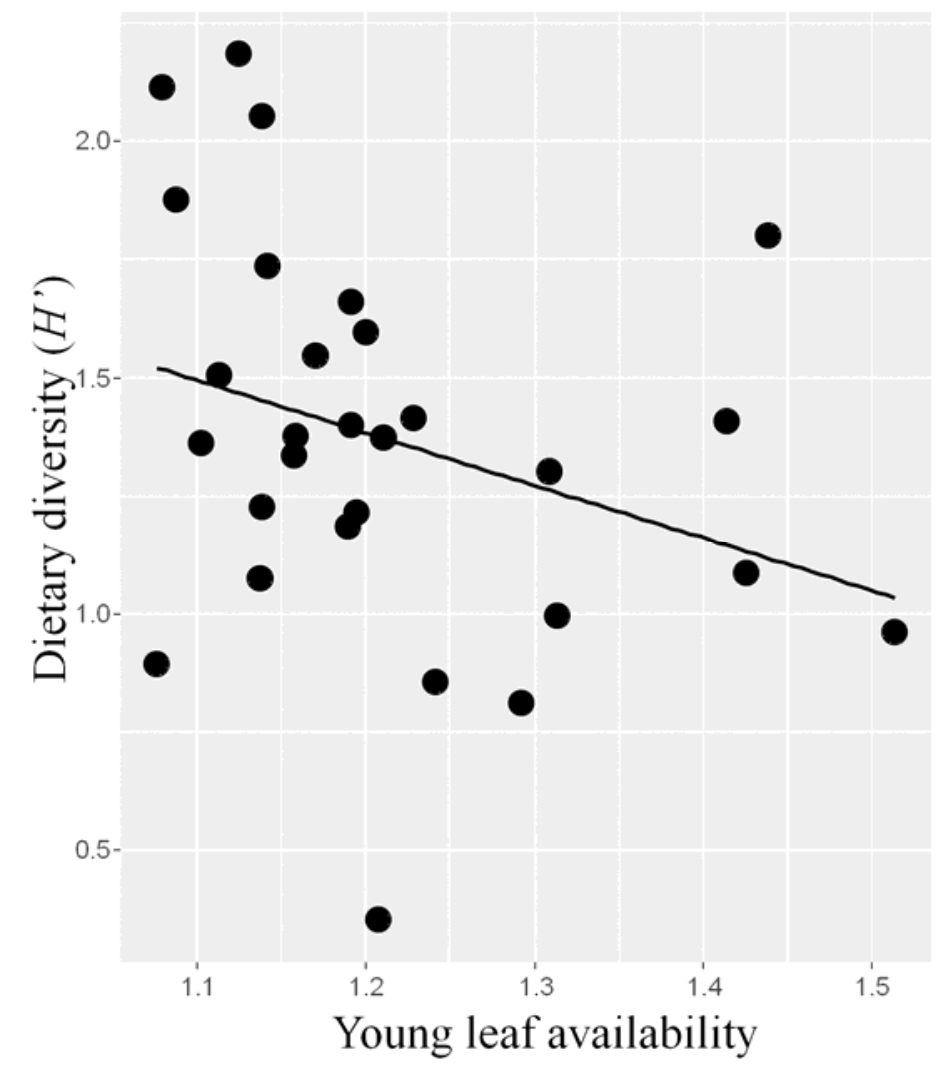

Figure 4. Relationship between the monthly availability of young leaves and dietary diversity. 